\title{
ARTIKEL AUDIT SISTEM INFORMASI MENGGUNAKAN FRAMEWORK COBIT 4.1 PADA PT. ANEKA SOLUSI TEKNOLOGI
}

\author{
Sulistyawati \\ 155100094 \\ Universitas Mitra Indonesia, Sistem Informasi \\ Sulistyawati.student@umitra.ac.id
}

\begin{abstract}
ABSTRAK
Salah satu bidang yang sangat pesat kemajuannya adalah Information Technology (IT) atau Information Systems (IS). Berkembangnya IS membawa dampak yang cukup signifikan bagi setiap perusahaan. Implementasi sistem informasi dilakukan untuk menunjang aktifitas proses bisnis tersebut. Hal yang sama dilakukan oleh PT. Aneka Solusi Teknologi yang didirikan pada tahun 2004, adalah perusahaan penyedia jasa perbaikan kualitas serta penyelesaian masalah yang terjadi pada elektronik, komputer dan mobile phone dengan cakupan layanan nasional. Objek penelitian meliputi bagian penjualan, pembelian dan gud ang. Perangkat lunak yang digunakan oleh perusahaan adalah M-Care Sistem dan ESA Sistem. Audit dilakukan untuk analisis dan mengetahui keamanan dan integritas data dari sistem informasi yang digunakan. Audit menggunakan framework COBIT 4.1. Domain yang digunakan adalah Delivery Support (DS), karena domain ini mencakup pengelolaan kelancaran dan keamanan sistem serta pengelolaan data dan operasional fasilitas.
\end{abstract}

Kata Kunci: audit framework 


\section{A.PENDAHULUAN}

Seiring perkembangan zaman yang semakin modern serta kemajuan era globalisasi mendorong masyarakat untuk dapat menyesuaikan diri dengan lingkungannya. Begitu pula dengan perusahaan yang harus beradaptasi dengan kemajuan teknologi supaya dapat meningkatkan keuntungan pada perusahaan.

Oleh karena itu diperlukan penerapan audit system informasi dengan mengggunakan COBIT atau control objectives for information and related technology. PT. Aneka Solusi Teknologi merupakan perusahaan yang bergerak di bidang jasa perbaikan mutu kualitas serta penyelesaian masalah pada berbagai elektronik computer dan handphone. Perusahaan tesebut pada saat ini sedang dalam tahap penerapan audit system informasi. Peranan SI/TI yang sangat signifikan harus diimbangii dengan pengaturan dan pengelolaan yang tepat sehingga kerugian atau ancaman yang mungkin terjadi dapat dihindari.

Adapun tujuan dari penerapan audit sistem ini adalah untuk mengevaluasi dan menjadikan hasil audit sebagai masukan untuk memperbaiki pengelolaan sistem berjalan pada PT. AST sehingga dapat mewujudkan tujuan IT perusahaan tujuannya yaitu memiliki integrated ERP untuk lini bisnis service ini. Audit yang dilakukan pada perusahaan mengenai tata kelola TI (Teknologi Informasi) pada keamanan data yang sedang berjalan. 


\section{B.TINJAUAN PUSTAKA}

Audit sebagai proses pengumpulan dan evaluasi bukti informasi yang dapat diukur pada suatu entitas ekonomi yang membuat kompeten dan independen untuk dapat menentukan dan melaporkan informasi sesuai dengan kriteria yang telah ditetapkan. Audit harus dilakukan oleh independen dan kompeten. (Arens dan Loebbecke, 2003),

Audit sistem informasi adalah proses pengumpulan dan penilaian bukti - bukti untuk menentukan apakah sistem komputer dapat mengamankan aset, memelihara integritas data, dapat mendorong pencapaian tujuan organisasi secara efektif dan menggunakan sumberdaya secara efisien(Ron Weber 1999,10)

Framework/ kerangka kerja adalah sebuah software untuk memudahkan para programmer membuat aplikasi atau web yang isinya adalah berbagai fungsi, plugin, dan konsep sehingga membentuk suatu sistem tertentu

\section{C.STUDI KASUS}

Penerapan audit informasi menggunakan cobit melalui beberpa proses:

1. DS1 define and manage service levels. Proses ini bertujuan untuk mengetahui sudahkah ada komunikasi efektik antara manajemen TI dan pelanggan.

\section{DS2 Manage Third-party Services}

Proses ini merupakan kebutuhan untuk memastikan untuk memastikan bahwa layanan yang diberikan oleh pihak ketiga (pemasok, vendor dan mitra) memenuhi persyaratan bisnis memerlukan proses manajemen pihak ketiga yang efektif.

\section{DS3 Manage Performance and Capacity}

Proses ini merupakan kebutuhan untuk mengelola kinerja dan kapasitas sumber daya TI untuk meninjau secara berkala kinerja dan kapasitas smber daya TI saat ini

\section{DS4 Ensure Continuous Service}

Kebutuhan untuk menyediakan layanan TI berkelanjutan memerlukan pengembangan, pemeliharaan dan pengujian rencana kesinambungan TI, memanfaatkan penyimpanan cadangan di luar kantor dan menyediakan pelatihan rencana kontinuitas secara berkala. Proses pelayanan berkelanjutan yang efektif 
meminimalkan kemungkinan dan dampak dari gangguan layanan TI utama terhadap fungsi dan proses bisnis utama.

5.DS5 Ensure Systems Security

Kebutuhan untuk menjaga integritas informasi dan melindungi asset TI memerlukan proses manajemen keamanan. Proses ini mencangkup pembentukan dan pemeliharaan peran keamanan TI dan tanggungjawab kebijakan standar, dan prosedur manajemen.

6. DS6 Identify and Allocate Costs

Kebutuhan akan sistem pengalokasian biaya TI untuk bisnis membutuhkan pengukuran akurat dari biaya TI dan kesepakatan dengan pengguna bisnis pada alokasi yang baik.

Proses ini mencangkup pembangunan dan pengoperasian system untuk menangkap mengalokasi dan melaporkan biaya TI kepada pengguna layanan.sistem alokasi yang baik memungkinkan perusahaan membuat keputusan yang tepat terkait pengguna layanan $\mathrm{TI}$.

\section{DS7 Educate and Train Users}

Proses ini memastikan edukasi yang efektif untuk semua pengguna sistem TI, termasuk yang ada di dalam TI, Memerluksn identifikasi kebutuhan pelatihan setiap kelompok pengguna Selain mengidentifikasi kebutuhan, proses ini mencakup penentuan dan pelaksanaan strategi untuk pelatihan yang efektif dan mengukur hasilnya

8.DS8 Manage Service Desk and Incidents

Respons tepat waktu dan efektif terhadap pertanyaan dan masalah pengguna TI memerlukan meja layanan dan proses manajemen kejadian yang dirancang dengan baik. Proses ini mencakup pengaturan fungsi meja layanan dengan registrasi, peningkatan kejadian, analisis trend dan akar penyebab, dan resolusi. Manfaat bisnis mencakup peningkatan produktivitas melalui penyelesaian cepat permintaan pengguna.

9. DS9 Manage the Configuration

Memastikan integritas konfigurasi perangkat keras dan perangkat lunak memerlukan penetapan dan pemeliharaan repositori konfigurasi yang akurat dan 
lengkap. Proses ini mencakup mengumpulkan informasi konfigurasi awal, membuat baseline, memverifikasi dan mengaudit informasi konfigurasi, dan memperbaharui konfigurasi repositori sesuai kebutuhan. Manajemen konfigurasi yang efektif memfasilitasi ketersediaan sistem yang lebih besar, meminimalkan masalah produksi.

10. DS10 Manage Problem

Manajemen masalah yang efektif memerlukan identifikasi dan klasifikasi masalah, analisis akar penyebab dan penyelesaian masalah. Proses manajemen masalah juga mencakup rumusan rekomendasi untuk perbaikan, pemeliharaan catatan masalah dan penelaahan status tindakan korektif.

\section{DS11 Manage Data}

Pengelolaan data yang efektif memerlukan identifikasi kebutuhan data. Proses pengelolaan data juga mencakup penetapan prosedur yang efektif untuk mengelola media library, backup dan pemulihan data, dan pembuangan media yang tepat. Pengelolaan data yang efektif membantu memastikan kualitas, ketepatan waktu dan ketersediaan data bisnis.

\section{DS12 Manage the Physical Environment}

Perlindungan untuk peralatan komputer dan personil memerlukan fasilitas fisik yang dirancang dengan baik dan dikelola dengan baik. Proses pengelolaan lingkungan fisik meliputi penentuan persyaratan lokasi fisik, pemilihan fasilitas yang tepat, dan perancangan proses yang efektif untuk memantau faktor lingkungan dan mengelola akses fisik. Pengelolaan lingkungan fisik yang efektif mengurangi gangguan bisnis dari kerusakan peralatan komputer dan personil.

\section{DS13 Manage Operations}

Pengolahan data yang lengkap dan akurat memerlukan pengelolaan prosedur pengolahan data yang efektif dan perawatan perangkat keras yang rajin. Proses ini mencakup penentuan kebijakan dan prosedur operasi untuk pengelolaan yang efektif untuk pemrosesan terjadwal, melindungi keluaran sensitif, memantau kinerja infrastruktur dan memastikan 


\section{D.DISKUSI}

Kapasitas dan kinerja TI yang ada pada perusahaan saat ini sudah cukup baik, namun penanganannya masih bersifat informal. Belum ditemukan kendala apapun pada kinerja TI. Untuk perencanaan masa depan mengenai kapasitas dan kinerja IT direncanakan berdasarkan fungsi pekerjaan (akan dikembangkan)

Untuk pengalokasian dana terkait layanan TI yang digunakan masih terbatas pada apa yang dikeluarkan untuk kebutuhan dasar-dasar saja.

\section{E.KESIMPULAN DAN SARAN}

\section{Kesimpulan}

Kapasitas dan kinerja TI yang ada pada perusahaan saat ini sudah cukup baik, namun penanganannya masih bersifat informal. Belum ditemukan kendala apapun pada kinerja TI. Untuk perencanaan masa depan mengenai kapasitas dan kinerja IT direncanakan berdasarkan fungsi pekerjaan (akan dikembangkan) Untuk pengalokasian dana terkait layanan TI yang digunakan masih terbatas pada apa yang dikeluarkan untuk kebutuhan dasar-dasar saja.

Secara keseluruhan, sistem aplikasi yang terdapat pada PT. AST sudah berjalan cukup baik,dilihat dari nilai current maturity level yang tidak berada jauh dari expected maturity level yang diharapkan. Hanya saja masih diperlukan adanya pengembangan sistem agar aplikasi

tersebut menjadi lebih baik.

\section{Saran}

Sistem dikembangkan, sekalipun belum mengalami kendala, namun permasalahan yang bisa saja terjadi seharusnya sudah dapat dipertimbangkan dan di identifikasi terlebih dahulu sebagai bentuk antisipasi 
Pemberian latihan secara khusus kepada bagian manajerial TI untuk dapat mengelola, merawat, serta memelihara keberlangsungan layanan sistem yang ada. Termasuk diantaranya pelatihan untuk audit sistem agar bisa mengevaluasi apa saja kekurangan yang terdapat pada sistem yang sedang berjalan di perusahaan serta penanganannya.

\section{F.REFERENSI}

[1] PUTRA, Arie Setya; FEBRIANI, Ochi Marshella. Knowledge Management Online Application in PDAM Lampung Province. In: Prosiding International conference on Information Technology and Business (ICITB). 2018. P. 181-187.

[2] FEBRIANI, Ochi Marshella; PUTRA, Arie Setya. Sistem Informasi Monitoring Inventori Barang Pada Balai Riset Standardisasi Industri Bandar Lampung. Jurnal Informatika, 2014, 13.1: 90-98

[3] Putra, A. S. (2018, July 9). 2018 Artikel Struktur Data , Audit dan Jaringan Komputer. Retrieved from osf.io/3uq8w

[4] candra, fenny (2017,November).audit system informasi.jurnal informatika.

[5]http://ridwansantosoug.blogspot.com/2014/11/pengertian-audit-sisteminformasi.html 